\title{
THE COURTS, THE COMMON LAW, AND THE CONSTITUTIONAL IMPERATIVE: BEYOND DOLPHIN DELIVERY*
}

BY ALLAN DOMES**

The author surveys perceived flaws in the Supreme Court of Canada's decision in the Dolphin Delivery Case. The article then attempts to define the scope of s. 32 of the Charter in light of post-Dolphin jurisprudence.

\section{TABLE OF CONTENTS}

I. INTRODUCTION

II. THE DISTINCTION BETWEEN PRIVATE ACTION

AND PRIVATE LITIGATION

III. THE DECISION IN DOLPHIN DELIVERY

A. The Substantive Analysis Under Section 2(b) and Section $1 \ldots$

B. Does the Charter Apply to the Common Law .............

C. Does the Charter Apply to Private "Litigation"? ..........

D. A Dash of Criticism .........................

1. Private Action vs. Private Litigation

2. Application to the Common Law: Merely a Piece, or the Whole Pie?

3. The Charter and the Courts $\ldots \ldots \ldots \ldots \ldots \ldots \ldots \ldots, 442$

4. A Fresh Perspective $\ldots \ldots \ldots \ldots \ldots \ldots \ldots \ldots \ldots, 444$

IV. THE FALLOUT $\ldots \ldots \ldots \ldots \ldots \ldots \ldots \ldots \ldots \ldots \ldots \ldots \ldots \ldots \ldots \ldots \ldots$

A. The Meaning of "Government" ............... 447

B. The Meaning of Government "Action" ............. 448

1. Omission ............................... 448

2. The "Administration of Justice" Cases ........... 451

3. Direct Application to Positive Rules of the Common Law ... 452

4. McIntyre J's "Lifeline" ......................... 459

V. CONCLUSION $\ldots \ldots \ldots \ldots \ldots \ldots \ldots \ldots \ldots \ldots \ldots \ldots, 460$

\section{INTRODUCTION}

With the 1986 decision of the Supreme Court of Canada in Retail, Wholesale and Department Store Union, Local 580 v. Dolphin Delivery Ltd., ' it was no doubt hoped that certain fundamental questions about the application of the Canadian Charter of Rights and Freedoms ${ }^{2}$ would be answered. It is equally undoubtable that, in the aftermath of this decision from Canada's highest judicial authority, there is perhaps as much room for judicial and academic debate, and certainly more confusion.

* This article was one of the winning entries in the William Morrow Essay contest.

** Student-at-law with the firm Milner \& Steer, Edmonton.

1. [1986] 2 S.C.R. 573, 33 D.L.R. (4th) 174. Hereinafter referred to as Dolphin Delivery. All page references are to 33 D.L.R. (4th).

2. Part I of the Constitution Act, 1982, as enacted by the Canada Act, 1982 (U.K.), c.11. Hereinafter referred to as the Charter. 
At no risk of hyperbole, one would have to say that the question of the scope of the Charter's application has proven a very vexed one. Since the Charter's introduction in 1982 as part of Canada's constitutional framework, a furious debate has raged among academics over the meaning of s.32 of the Charter and its relationship to other Constitutional provisions, and particularly its potential embrace of private action. It is a debate that has led nowhere other than to highlight some of the inherent difficulties in Charter litigation, aligning participants on opposite sides of an interpretive conundrum.

Having reached a stalemate, the participants in this exchange presumed that $\mathrm{Dol}$ phin Delivery would vindicate one side and vanquish the other. Instead, the Supreme Court of Canada delivered, it is submitted, a remarkably inconsistent judgment that seemed to come down on one side of the debate, yet which opened the door to a further series of difficulties, most notably the application of the Charter to the Courts and the common law. As a result, lower courts have been forced to struggle with an unsatisfactory interpretation of the Charter's scope. Emerging from this struggle already are a number of judicial filaments that seek to bind constitutionally the common law in various respects. While these filaments are insufficient yet to weave a complete tapestry, nevertheless they reveal an underlying framework for Charter application.

The author proposes to examine the distinction between private action and private litigation and the importance of that distinction in the context of any discussion of the "constitutionalization" of the common law, and to analyze the effect of Dolphin Delivery and the developing framework of Charter application to the common law.

\section{THE DISTINCTION BETWEEN PRIVATE ACTION AND PRIVATE LITIGATION}

From the moment of the Charter's introduction, two camps of writers adopted nearly polar views of its application. One camp concluded that the Charter, given its nature as a constitutional document, given its legislative history, and given the wording of s.32, could only apply to the public sector - that is, the relationship between government and the citizen, rather than between citizen and citizen. ${ }^{3}$ Thus, the Charter could not apply directly to litigation between purely private parties. The other camp, relying on substantially the same sources of argument, reached a directly contrary result: the Charter could, and should, apply in private disputes between citizens, in addition to disputes between citizen and government. ${ }^{4}$ For ease of reference, I adopt the taxonomy proposed by Donald Buck-

3. See P. Hogg, Constitutional Law of Canada (2nd ed. 1985) 670; K. Swinton, “Application of the Canadian Charter of Rights and Freedoms (Ss. 30, 31, 32)" in W.S. Tamopolsky and G.-A. Beaudoin (eds.), The Canadian Charter of Rights and Freedoms: Commentary (1982) 41; A. McLellan and B. Elman, "The Enforcement of the Canadian Charter of Rights and Freedoms: An Analysis of s.24(1)" (1983) 21 Alia. L. Rev. 204, "To Whom Does the Charter Apply? Some Recent Cases on s.32" (1986) 24 Alta. L. Rev. 361.

4. See D. Gibson, "The Charter of Rights and the Private Sector" (1982) 12 Man. L. J. 213, "Distinguishing the Governors from the Governed: The Meaning of 'Government' under Section 32(1) of the Charter" (1983) Man. L. J. 505, "Tort Law and the Charter of Rights" (1987) 16 Mar. L. J. 1; M. Manning, Rights, Freedoms and the Courts. A Practical Analysis of the Constitution Act, 1982 (1983) 115. 
ingham to describe these groups: the "public-only" and "private-too" camps respectively. ${ }^{5}$

In fact, it is misleading to talk in this regard with reference to "litigation" and "disputes" between private parties, for the "public-only" camp, for the most part, acceded to the likelihood that the Charter would apply to private litigation. Where private parties are involved in a legal dispute, and where one party relies, for example, on a legislative provision, it is open to the other party to raise the Charter to challenge that legislative provision. ${ }^{6}$ The public-only camp would, however, deny the applicability of the Charter to purely private action as distinguished from government action. For the purposes of the present discussion, the author is prepared to assume that s.32 only encompasses government action, whatever that may include, so that "private action" as it is explained below will be excluded from Charter review.

The distinction between private action and private litigation is best illustrated by an example. Suppose an ardent supporter of free choice with respect to abortion, wanting to create new discussion and to generate fresh debate, approaches a landowner, who happens to be in the business of letting land for advertisement purposes, and requests permission to erect a large billboard that will proclaim his beliefs. The landowner, either because he does not wish to involve himself in the debate or because he believes fervently in the "right to life", refuses permission to erect the billboard. What can the "free choice" supporter do? In the absence of any legislation to the contrary, he has not cause of action against the landowner. Since it is a purely private act of "discrimination" broadly speaking, and we have assumed that only government action is caught by the Charter, s.24(1) does not give him a "constitutional tort" action on the basis of an alleged infringement of his Charter rights (probably freedom of expression in this case).

Changing the facts slightly, we find the would-be activist renting premises from the landowner. However, the landowner being a particularly devout supporter of the right to life, a term of the lease prohibits the erection of any sign or display that would advocate or countenance the right to choose abortion. Undaunted, the intrepid tenant constructs a billboard announcing his position on the abortion issue. After demanding the dismantling of the sign and being refused, the infuriated landowner commences an action against the tenant for breach of the terms of the lease. It would seem quite clear that the tenant has breached the lease and that the landlord has a good cause of action against the tenant, quite independently of s.24(1) of the Charter. The issue then becomes, in the context of this private dispute or litigation, whether the Charter has any application - i.e. as a defence available to the tenant. If a provision of the relevant landlord and tenant legislation expressly permitted the insertion into a lease of a term such as the one in question and the landlord relied on this provision, the Charter would clearly be available to the tenant, ${ }^{7}$ and if the legislative provision, in the context of the private litigation, were found inconsistent with the Charter and not a reasonable limit under s.1, then it would be declared of no force and effect.

5. D. Buckingham, "The Canadian Charter of Rights and Freedoms and Private Action Applying the Purposive Approach"' (1987) 51 Sask. L. Rev. 105.

6. Curiously enough, some writers considered this proposition to be debatable. See, e.g., B. Slattery, "Charter of Rights and Freedoms - Does it Bind Private Persons" (1985) 63 Can. Bar Rev. 148 at 152.

7. As will be seen later, a legislative provision may not be necessary. 
The distinction can be summarized as follows: the Charter is successfully invoked in the second fact situation because 1) the parties are involved in a private litigation that has arisen independently of any notion of "constitutional tort"; 2 ) one party - the landlord - relies on government action in the form of provincial legislation to support his infringement of the tenant's Charter rights. In the first fact situation, there is no government action, not even any private litigation. There is merely a purely private act of one person toward another that generates no legal recourse in the other (again, barring the existence of any relevant human rights legislation) independently of the Charter.

It must be noted that this distinction may depend for its cogency on a particular theory of law and freedom. While such discussions are best left to scholars of legal philosophy, the essence of this theory and its countertheory must be set out. The countertheorists posit "legal plenitude" as the major premise of their argument: they would see the "law" as including all those things not expressly, or by necessary implication, prohibited or permitted by common law or legislative rules. In this sense, one can refer to these "permissions" as "tacitly permissive law". If such tacit permissions were "law" properly said, then any private act purportedly based on such permission would be subject to the Charter. Thus, in the first fact situation set out above, the landlord's refusal to allow the tenant to erect the billboard, even though not expressly or by necessary implication permitted by common law or statute, nevertheless, since it is not expressly or by necessary implication prohibited, it is action pursuant to a tacitly permissive "law" and therefore would be subject to Charter scrutiny. As Professor Gibson states

It has long been one of our most fundamental bulwarks of freedom that the law permits whatever it does not clearly proscribe. Viewed against this notion of the law's plenitude, it is possible to regard all private conduct as subject to the law, and therefore to the Charter. ${ }^{8}$

If the "law" permits one to do something in derogation of a right enunciated in the Charter, the argument goes, then the Charter should apply to proscribe that behaviour. In this way, the Charter could make significant inroads into the activity of the private sector.' Indeed, if the "common law" were to include those acts impliedly permitted merely because there are no positive rules proscribing those acts, the Charter would be directly applicable to a private act of discrimination not prohibited by, say, a provincial human rights code.

The better view would seem to be that the express or necessarily implied prohibitions and permissions embodied in common law and legislative rules carve out a chunk of what would otherwise be plenary freedom. Thus, private action taken pursuant to such a freedom would not be caught by the Charter, but action taken pursuant to a positive rule of law would be caught. In fact, it seems odd to suggest that the Charter should apply to such "freedoms" since s. 26 thereof provides that

The guarantee in this Charter of certain rights and freedoms shall not be construed as denying the existence of any other rights or freedoms that exist in Canada.

It might be said that it is a fundamental freedom of Canadians to engage in activity that is not proscribed by law (leaving aside questions of morality). This freedom should, then, be protected by our Constitution, not abridged by it.

8. Gibson, "The Charter of Rights and the Private Sector," supra n.4 at 218.

9. For a discussion of the effect such "back door" reasoning would have on provincial human rights legislation, see K. Norman, "The Charter for the Public Sector and for the Private Sector, Human rights Codes: A False Dichotomy, Leading to the Wrong Result"' (1984) 5 C.H.R.R. C/84-5. 
In the end, however, both theories mask a different fallacy as far as the application of the Charter is concerned. The fallacy lies in the assumption that merely because something is "law" it must be caught by the Charter. The argument, strongly supported by Professor Gibson, proceeds on the footing that because s.52(1) of the Constitution Act, $1982^{10}$ refers to "any law", therefore the Charter will apply to tacitly permissive law. While no doubt any "law" that is inconsistent with the Charter must be struck down by virtue of s.52(1), before the "law" can ever be measured against the Charter, it must, as we have assumed, be shown to have some nexus with government action: it is s.32(1) that defines the types of "law" that are caught by the Charter, not s.52(1)." In any event, since the key is to show some nexus with government, the argument that tacit permissions are law may be moot except with respect to the availability of a remedy: assuming that a governmental nexus can be shown, then if tacit permissions are law, a remedy would be sought under s.52(1). If they are not law, but they evidence government acts other than law, then a remedy would be sought under s.24(1). The only other counterargument to the suggestion that it is irrelevant whether tacit permissions are law or not proceeds as follows, that since s. 1 only allows reasonable limits "prescribed by law", infringements on the basis of tacit permissions would never be justifiable because the permissions are not law. However, there would seem to be no merit to this argument as when attacking a purely governmental act (e.g. a Cabinet decision), nevertheless, it can be a reasonable limit under s.1.12

The conclusion to be drawn from the foregoing discussion is simply that there is a very real distinction between the concepts of private action and private litigation. Furthermore, assuming that the Charter only applies to government action, it cannot apply to private action, though it may very well apply in the context of private litigation. Finally, as will become clearer in the discussion of Dolphin Delivery, it is imperative to maintain this distinction when dealing with the question of the Charter's application to the common law.

Long before the Supreme Court of Canada decided Dolphin Delivery, commentators on both sides of the private/public debate were suggesting the possible application of the Charter directly to rules of the common law, section 52(1) of the Constitution Act, 1982 being seen as the key in this regard. Recalling the wording of s.52(1), one notes that where "any law" is found to be inconsistent with the Charter, it will be of no force or effect to the extent of that inconsistency. Relying in support on the French text of s.52(1) which reads "toute autre règle de droit" rather than the narrower term "loi", ${ }^{13}$ Gibson concludes that "any law" must

10. S.52(1) provides for the supremacy of the Constitution and reads

52(1) The Constitution of Canada is the supreme law of Canada, and any law that is inconsistent with the provisions of the Constitution is, to the extent of the inconsistency, of nor force or effect.

11. On this point, see the particularly strong words of Ghislain Otis:

[T] he role of subsection 52(1) is not to define the scope of application of the Charter, as some writers mistakenly maintained, but to affirm its supreme status and thus dispel any doubt the courts might entertain as to their power of review. The supremacy of the Charter may not go beyond the reach of the Charter itself. The words "any law" in subsection 52(1) must therefore be fitted within the limits set in subsection 32(1).

G. Otis, "The Charter, Private Action and the Supreme Court" (1987) 19 Ott. L. Rev. 71 at 73.

12. E.g. Operation Dismantle v. The Queen [1985] 1 S.C.R. 441.

13. "Loi"' is generally used to refer to an Act. 
include both legislation and rules of the common law. Hogg, in contrast, does not fully support his position, merely saying that " $[t]$ he Charter will apply to any rule of the common law that specifically authorizes or directs an abridgement of a guaranteed right". ${ }^{14}$ Similar faith in the applicability of the Charter to common law rules is expressed by John Baigent and Jeffrey Hoskins: "[I]t would seem clear that the common law itself is subject to the Charter simply because judge-made law is law, and the Charter is the supreme law". ${ }^{\text {is }}$

Of course, the "public-only" and "private-too" camps make different uses of their superficially similar conclusion. The "private-too" group, led by Professor Gibson, would see the Charter applying to all aspects of private life, based on a "legal plenitude" theory outlined above. Hogg recognizes the "implied permission" argument, but suggests, quite rightly it is submitted, that "[i]f the Charter applied to the common law in that attenuated sense, it would apply to all private activity" ${ }^{16}$ Given his view that the Charter is a document regulating the relationship between individual and the state, his suggestion for a compromise comes as little surprise. This compromise he outlines as follows:

[I]t seems more reasonable to say that the common law offends the Charter only when it crystallizes into a rule that can be enforced by the courts. Then, if an enforcement order would infringe a Charter right, the Charter will apply to preclude the order, and, by necessary implication, to modify the common law rule. ${ }^{17}$

The difference between Hogg's approach and that of Professor Gibson lies in Hogg's predicating his view on the assumption that court enforcement of crystallized rules, whether statutory or common law, embodies the element of "state action" necessary to bring such enforcement (and thereby the rules themselves) under the scrutiny of the Charter. That is to say, his view is not based on the proposition that s.52(1) makes the whole common law amenable to the Charter by virtue of the common law being law. No doubt Professor Hogg is made uneasy by the vaguely tautologous reasoning in such an argument. ${ }^{18}$

In summary, then, we find two apparently valid arguments, awaiting the judiciary to test their cogency. The "private-too" group would see the Charter applying to everyone directly; the "public-only" group would see the Charter applying to anyone involved in a dispute, whether public or private, who can demonstrate a governmental action that has the effect of infringing a Charter right or freedom. In between them falls the question of the constitutionalization of the common law. The stage is then set for the delivery of Dolphin by the Supreme Court of Canada.

14. Hogg, supra, note 3, at 677 . On the question of the relevance of s.52(1) to this question, Hogg has the following to say, in note 145 accompanying his text at 678 :

[I]t is irrelevant that the word "law" in ss.1 and 52(1) includes the common law (as I have no doubt it does); those two sections are only engaged after it has been determined that a rule of the common law is inconsistent with a Charter right; and in my view there is no such inconsistency until the common law rule has crystalized into a form that is enforceable by court onder.

15. J. Baigent and J. Hoskins, "Govemment Action: Federal and Provincial Govemments and Others as Defendants," in G.-A. Beaudoin (ed.), Charter Cases 1986-87 (1987) 113 at 117.

16. Hogg, supra n.3 at 678 .

17. Id.

18. Professor Gibson, in his 1983 article, "Distinguishing the Governors from the Governed, supra, note 4, alludes to this dual reasoning, effectively adopting both positions (at 514): “ . . . judge-made law is, in my opinion, both a "law" within the meaning of section 52(1) and a product of govemmental activity within the meaning of section $32(1) "$. 


\section{THE DECISION IN DOLPHIN DELIVERY}

While few students of post-Charter constitutional law in Canada will be unfamiliar with the essential facts in Dolphin Delivery, ${ }^{19}$ those facts do bear repeating. Dolphin Delivery Ltd. was a courier operating in Vancouver, B.C., and the surrounding area, contracting with Purolator Courier (an Ontario-based, but federally incorporated company) to do such courier work in the Vancouver area. The employees of Purolator's Ontario operation became involved in a labour dispute with their employer, which resulted in strike action against Purolator. Meanwhile, Dolphin Delivery had contracted with another courier, Supercourier, in a manner very much the same as it had with Purolator. It was alleged by the union representing the striking Purolator employees that Supercourier was in some manner connected to Purolator. The union sought to have both Dolphin Delivery and Supercourier declared allies of Purolator, in order to permit the union to engage in secondary picketing of these couriers. The British Columbia Labour Relations Board, which heard the application, declined to make the declaration on the basis that it had no jurisdiction: Purolator was a federally incorporated company so that the Canada Labour Code $e^{20}$ was the relevant legislation. Since the Code did not contain a provision dealing with secondary picketing, the parties agreed that the question of whether the secondary picketing of Dolphin Delivery and Supercourier was lawful would fall to be determined by the common law.

The union notified Dolphin of its intention to picket. Dolphin made an application for an interlocutory injunction to prohibit the picketing until after the trial of the action to determine its lawfulness. The injunction was granted on the basis that the threatened picketing was not for the purpose of "dissemination of information and the protection of the defendant's interest", ${ }^{21}$ but rather for the purpose, inter alia, of inducing Dolphin to breach its contract with Purolator, a common law tort.

On appeal, the union argued that the common law principles upon which the chambers judge rested his decision infringed the Charter's guarantee of freedom of expression, contained in s.2(b), as well as the guarantee of freedom of association, contained in s.2(d). The majority of the British Columbia Court of Appeal held that picketing was neither a protected form of expression, nor a protected form of association under the Charter. However, the court said, even if picketing were so protected, the injunction based on the tort of inducing breach of contract was a reasonable limit under s.1.The application of the Charter to the common law was not disputed in the Court of Appeal.

The union's appeal to the Supreme Court of Canada was limited to whether picketing was a protected form of expression under s.2(b) of the Charter, and if so, whether the injunction granted in chambers constituted a reasonable limit thereto under s. 1. It was in the context of his s. 1 analysis that McIntyre J. ran up against the question of the Charter's application to the common law.

19. Supra n.1.

20. R.S.C. 1970 , c.L-1.

21. Per Sheppard L.J.S.C., [1983] B.C.W.L.D. 100. 


\section{A. THE SUBSTANTIVE ANALYSIS UNDER SECTION 2(b) AND SECTION 1}

McIntyre J., who delivered the judgment of the majority, began by noting the dearth of evidence upon which the Supreme Court was being asked to decide an important constitutional question. Nevertheless, he was prepared to proceed on the basis of assumptions and meagre findings of fact of the chambers judge and the Court of Appeal. The judgment must be read with this factual anemia in mind.

Given his later ruling that the Charter could have no application to the case, McIntyre J.'s analysis of picketing as a form of expression protected under s.2(b) and his subsequent conclusion that the injunction represented a reasonable limit under s. 1 must be regarded as obiter dicta. Other than to note the inconsistency between these findings and his major finding with respect to the Charter's application to the common law, we need not be overly concerned about the substance of McIntyre J.'s analysis in this part of his judgment.

\section{B. DOES THE CHARTER APPLY TO THE COMMON LAW?}

Mr. Justice McIntyre begins with the promising proposition that the Charter undoubtedly applies to the common law. He seems to adopt the reasoning of Professor Gibson when he says:

To adopt a construction of s.52(1) which could exclude from Charter application the whole body of the common law which in great part governs the rights and obligations of the individuals in society, would be wholly unrealistic and contrary to the clear language employed in s.52(1) of the Act. ${ }^{22}$

In fact, McIntyre J. may really be accepting the position of Hogg, namely that the common law, to some extent, will be amenable to Charter review. However, the extent of its subjection must be determined according to the meaning that is attached to s.32(1).

\section{DOES THE CHARTER APPLY TO PRIVATE “'LITIGATION'?}

The court having adopted the position that the common law must be amenable to Charter review, one would have expected it to proceed either along the path laid down by Professor Hogg, or that laid down by Professor Gibson. At least one would have expected them to perform a detailed analysis of these arguments. Instead, the court gives cursory treatment to the academic debate, and chooses neither path, striking off into uncharted territory.

Mr. Justice McIntyre frames the question in the following terms: "[D]oes the Charter apply to private litigation divorced completely from any connection with government?", ${ }^{23}$ [emphasis added]. Immediately, McIntyre J.'s use of the word "litigation" in place of the word "action" merits serious attention, especially since he turns to Hogg, Swinton, McLellan and Elman for support of his view that the answer to the question as framed is "No". In fact, while Swinton remains noncommital on the point, neither Professor Hogg nor Professors McLellan and Elman conclude that the Charter has no application in the context of private litigation, but rather that the Charter cannot be used to found new causes of action on the basis

22. Supra n.1 at $190-191$.

23. Id. at 191 . 
of private acts allegedly infringing rights guaranteed by it. All three academics accept the likelihood that the Charter will have a significant impact on private disputes because the laws governing such disputes will be subject to Charter scrutiny. What is denied is the private actor, claiming that another private actor has infringed his guaranteed right, trying to originate an action under s.24(1) of the Charter. ${ }^{24}$ The question of whether the Charter should apply to the common law, where both parties to the dispute are purely private (i.e. "non-governmental") is treated by these writers as separate, and answerable only with reference to s.32(1) and the meaning attributed to the word "government" therein. ${ }^{25}$

In fact, Justice McIntyre does go on to posit his view of the relationship between s.32(1) and s.52(1). Without noting the academic "hooplah" surrounding the meaning of s.32, he boldly asserts that "s.32 of the Charter, specifically dealing with the question of Charter application, is conclusive on this issue". ${ }^{26} \mathrm{He}$ then must engage in a further analysis of what is meant by the term "government", since s.32 only refers to Parliament, provincial legislatures and "government". Essentially, this approach follows that of Professor Hogg. That is, although s.52(1) clearly makes the common law subject to the Charter, it can only do so to the extent that the Charter applies under s.32(1). Yes, the common law must fall if inconsistent with the Charter, but if the common law cannot first be brought within its ambit by virtue of s.32(1) (i.e. is it "government action'?), the common law can never be inconsistent with the Charter.

It is at this juncture that Mr. Justice McIntyre embarks on a rather unsteady journey to determine whether the common law can be squeezed within the meaning of "government" in s.32(1). His starting point is the separate usage of "Parliament" (or "legislature") and "government", indicating that "government" is meant not to refer to the "whole of the governmental apparatus of the State" ${ }^{27}$ His premise must be that if the whole "apparatus" were intended, there would be need for only one noun (perhaps 'Government"?), not two. His conclusion, with very little reasoning offerred in support, is that "government" must mean the executive or administrative branch of government.

Of course, the argument of the union was that the common law was judge-made law, and the judiciary was a branch of government, and the common law was, therefore, subject to the application of the Charter. That is, if there must be government action before the Charter has any relevance to a dispute between private parties, then where the common law regulates, or defines, or applies to the dispute, one can locate the requisite government nexus in the fact that the common law is created

24. Section 24(1) reads:

24(1) Anyone whose rights or freedoms, as guaranteed by this Charter, have been infringed or denied may apply to a court of competent jurisdiction to obtain such remedy as the court considers appropriate and just in the circumstances [emphasis added].

The highlighted phrase must be taken to include the substance of the right, and also against whom the right may be claimed. The latter issue reflects the entire controversy: it would be entirely circular to conclude on the basis of s.24(1) alone that private action is caught.

25. B. Etherington, "Constitutional Law - Charter of Rights and Freedoms, Sections 2(b) and 1 - Application of the Charter to the Common Law in Private Litigation - Freedom of Expression - Picketing in Labour Disputes: Retail, Wholesale and Dept. Store Union, Local 580 v. Dolphin Delivery Ld." (1987) 66 Can. Bar Rev. 818 at 832 ff.

26. Supra n.1 at 194.

27. Id. 
by the judiciary, a branch of government. The argument is rooted in the analogy of a dispute between private parties, where their relationship is governed by provisions of statutory law. In such a case, the government nexus is found in Parliamentary or legislative enactment of the statute. When a court seeks to enforce one of the positive rules of the common law, it thereby becomes subject to the Charter and, if found inconsistent with the rights guaranteed in the Charter, the rule must be held to be of no force or effect to the extent of this inconsistency.

Mr. Justice McIntyre, however, was not open to the union's argument: To regard a court order as an element of governmental intervention necessary to invoke the Charter would, it seems to me, widen the scope of Charter application to virtually all private litigation. All cases must end, if carried to completion, with an enforcement order and if the Charter precludes the making of the order, where a Charter right would be infringed, it would seem that all private litigation would be subject to the Charter. ${ }^{28}$

Compounding the inherent difficulties with this ruling are McIntyre J.'s words immediately preceding it, that

[t] his is not to say that the courts are not bound by the Charter. The courts are, of course, bound by the Charter as they are bound by all law. It is their duty to apply the law, but in doing so they act as neutral arbiters, not as contending parties involved in a dispute 29

and further on that the courts "ought to apply and develop the principles of the common law in a manner consistent with the fundamental values enshrined in the Constitution" ${ }^{30}$ The effect of these pronouncements is that the common law, in toto, will not stand to be measured against the rights and freedoms enshrined in the Charter. Only to the extent that a rule of the common law reflects governmental action that a private party invokes or upon which he relies to infringe a Charter right, will the common law fall to be assessed under the Charter.

On the facts of the case, it was a dispute between two private parties and the only infringement of a Charter right alleged by the union was as a result of the injunction ordered by the chambers judge on the basis of the common law tort of inducing breach of contract. Accordingly, since there was no governmental action involved, the rule allowing a judge to enjoin a party from engaging in secondary picketing because it amounts to the tort of inducing breach of contract, could not be challenged under the Charter.

\section{A DASH OF CRITICISM}

The inconsistencies in the judgment of Mr. Justice McIntyre are legion, meriting serious attention, ${ }^{31}$ especially in light of the court's seemingly cavalier disposal of five years of academic and judicial comment on the central issue in the ruling.

28. Id. at 196.

29. Id.

30. Id. at 198.

31. Indeed, Professor Hogg questions whether more than one justice contributed to the written judgment, since "the inconsistencies and ambiguities are, with respect, uncharacteristic, and suggest an imperfect knitting together of two different opinions, one asserting and the other denying that the Charter applies to the common law." See P. Hogg. "The Dolphin Delivery Case: The Application of the Charter to Private Action" (1987) 51 Sask. L. Rev. 273 at 279. 


\section{Private Action vs. Private Litigation}

As we noted above, the distinction between private action and private litigation is an essential one, yet Mr. Justice McIntyre seems to run afoul of it in any event. His perfunctory conclusion that "the Charter does not apply to private litigation" [emphasis added] comes after he cites various authorities who attack the proposition that the Charter applies to private action, suggesting that his later ruling with respect to the common law may have been influenced by this misconception.

Commentators who have argued that the Charter should not be extended to private acts that infringe Charter rights and freedoms not only rely on the wording of s.32(1), but also on the existence of alternative remedial systems for rights infringement. For example, Professor Hogg notes:

The rights guaranteed by the Charter take effect only as restrictions on the power of government over the persons entitled to the rights. The Charter regulates the relations between govemment and private persons, but it does not regulate the relations between private persons and private persons. Private action is therefore excluded from the application of the Charter. Such actions as an employer restricting an employee's freedom of speech or assembly, a parent restricting the mobility of a child, or a landlord discriminating on the basis of race in his selection of tenants, cannot be breaches of the Charter, because in no case is there any action by the Parliament or government of Canada or by the Legislature or government of a province. In cases where private action results in a restriction of a civil liberty, there may be a remedy for the aggrieved person under a human rights code, under labour law, family law, tort law, contract law or property law, or under some other branch of the law governing relationships between private persons; but there will be no breach of the Charter ${ }^{32}$ [emphasis added].

His words are echoed and strengthened by Professors McLellan and Elman:

[I] is suggested that the better view is that the Charter applies only to government action. To hold otherwise would be to increase the scope of the Charter immeasurably. In cases involving arrests, detentions, searches and the like, to apply the Charter to purely private action would be tantamount to setting up an alternative tort system. In the area of private discrimination, an entirely new system of civil liability in competition with the dispute resolution mechanisms fostered by human rights legislation would result.

Arguably, human rights legislation provides a more efficient and less costly method by which individuals may seek redress for acts of private discrimination ${ }^{33}$ [emphasis added].

Nevertheless, Hogg, McLellan and Elman would not deny the applicability of the Charter in the context of private litigation. Where parties are involved in a legal dispute, and where one party relies on a legislative provision, it is open to the other party to raise the Charter to challenge the legislative provision. Furthermore, all three academics seem to endorse the possibility of the Charter applying to the common law when it is sought to be enforced through the courts. Therefore, McIntyre

32. Hogg, supra $\mathrm{n} .3$ at $\mathbf{6 7 4 - 6 7 5 .}$

33. McLellan and Elman, "To Whom Does the Charter Apply?" supra $n$.3 at 367-368. 
J.'s reliance on these authorities to exclude the Charter, in large measure, from the context of private litigation is entirely unconvincing. ${ }^{34}$

McIntyre J.'s adducing the Ontario Court of Appeal decision in Re Blainey and Ontario Hockey Association ${ }^{35}$ does little to mend the flaw in his initial reasoning. Justine Blainey was a 12-year-old girl seeking to retain her spot on an otherwise all-male hockey team. However, a regulation in the rules of the O.H.A. denied membership to females (except in very limited circumstances, which Blainey failed to meet), and O.H.A. membership was a prerequisite to membership on the allmale team. Blainey made a complaint of sex discrimination to the Ontario Human Rights Commission, but the Commission declined to hear the matter on the ground that s.19(2) of the Ontario Human Rights Code, $1981^{36}$ expressly permitted discrimination on the basis of sex in relation to membership in athletic organizations. Dubin J.A., speaking for the majority, declined to hold the Charter applicable to the regulation of the O.H.A. denying Blainey membership on the basis of sex. In his opinion, "s.15 of the Charter does not reach private activity within a province" ${ }^{37}$ Since he could not find any "nexus" between the government and the O.H.A., the regulations of that organization could not be directly challenged. However, the court was prepared to apply the Charter to s.19(2) of the Human Rights Code, 1981 in the context of the dispute between the two otherwise private parties, and concluded that s.19(2) did infringe Blainey's Charter rights under s.15(1) and was not a reasonable limit under s.1.38

34. At least one lower court has been beguiled by the language adopted by McIntyre in Dolphin. In Charters v. Harper (1987) 79 N.B.R. (2d) 28 (N.B.Q.B.), a criminal defendant brought a private action against a provincial court judge for breach of s.11(b) of the Charter - the right to be tried within a reasonable time. Richard C.J.Q.B. probably reached the right result when he concluded that a civil action based directly on a breach of the Charter should not be allowed, and that the proper remedy in the case was a quashing of the indictments against the accused (which had already been done by a superior court judge on the basis of s.11(b)). However, Richard C.J.Q.B. illustrates the potentially misleading quality of McIntyre J.'s terminology when he frames the issue, at 39, as "whether the Canadian Charter of Rights and Freedoms can be relied upon in a private action." Clearly, the Charter has application in a private "action" in the sense of a dispute between private parties and where one party relies on a statutory provision (at least) that infringes the Charter. Where the Charter should not apply, it seems, is in the case of a private act which directly infringes a Charter right.

35. (1986) 26 D.L.R. (4th) 728.

36. S.O. 1981, c.53.

37. Supra n.63 at 736 .

38. Note, however, the decision of the British Columbia Court of Appeal in Bhindi v. B. C. Projectionists Local 348 of Intl. Alliance of Picture Machine Operators of U.S. \& Can. (1986) 4 B.C.L.R. (2d) 145, [1986] 5 W.W.R. 303, 24 C.R.R. 302, which involved an attempt to apply the Charter directly to the terms of a collective agreement - in this case a closed-shop provision, the inclusion of which was authorized by statute. Relying on Blainey, the majority adopted the view that a private actor relying on express statutory authority does not thereby become a governmental actor so that its acts may be directly challenged. The majority, however, did not consider that the statutory provision authorizing the closed-shop provision was necessarily in issue so it did not apply the Charter even to the legislation. (This result seemed due to the way in which the relief was claimed in the pleadings.) Anderson J.A., in dissent, would have held that the discretionary power to insert a closed-shop provision did clothe the union with the vestments of government, so that the provision in question would be directly subject to attack. However, his conclusion seemed largely based on the historical treatment of trade unions and the fact that their contractual powers are far different from those of purely private persons. Hutcheon J.A., in a second dissenting opinion, would have held that s.9(1) of the Labour Code, R.S.B.C. 1979, c.212, which authorized inclusion of the closed-shop provision, was directly in issue. 
McIntyre J. in Dolphin Delivery no doubt relied on the court's unwillingness to extend the Charter to the "private action" in the form of the O.H.A. regulation as authority for his conclusion that the Charter cannot apply in private disputes short of there being some governmental action involved. However, Blainey is merely authority for the proposition that the Charter should not apply to purely private acts of discrimination, and says nothing about the scope of the Charter in the context of private litigation, except that where one party relies on a legislative provision in the context of a private dispute, that legislative provision must be subject to Charter scrutiny - hardly a controversial assertion.

\section{Application to the Common Law: Merely A Piece, or the Whole Pie?}

Having established that the Charter should not apply to private litigation except in limited circumstances (where one party invokes or relies on a governmental "act" to infringe a Charter right), McIntyre J. must then rationalize his position with respect to the common law. Because of his ill-conceived fear of extending the Charter to private "litigation", McIntyre J. is forced to limit the Charter's application to the common law. Any dispute between private parties must have its basis in legislative provisions (including subordinate legislation), or rules of the common law. If the Charter extended to the common law, therefore, as McIntyre J. concludes, it would have an untenable impact on private litigation. McIntyre J. gives no convincing reasons why the Charter should not have such a pervasive effect on private litigation. He has already concluded that where one party relies on a legislative provision in the context of a private dispute, the Charter clearly applies. As a result, we are faced with an arbitrary distinction between common law and statutory law: merely because a rule of the common law has been modified or adopted by statute, the Charter will apply, but where a common law rule has been left untouched by Parliament or a provincial legislature, a party is left without recourse. Anomalously, and somewhat ironically, civil litigants in Quebec, whose disputes are governed by the Civil Code, would be faced with greater Charter incursion than civil litigants in common law provinces, merely on the basis that the rules governing the relationship of the disputants in the former case have legislative authority, whereas in the latter case, the relevant rules merely have judicial authority.

\section{The Charter and the Courts}

The most telling argument for extending the Charter to the common law, and one that is discussed explicitly by the Supreme Court of Canada in Dolphin Delivery, is that if some element of governmental action is required before the Charter will apply, then it can be found in the judicial "creation" and enforcement of common law rules. Of course, McIntyre J. rejects this notion since he fears that any judicial ruling would be subject to Charter review. Moreover, he suggests that since the courts are merely "neutral arbiters", they really are not "acting" toward the common law in a way which could be called governmental - that is, they are not "creating" the law, merely applying it. In this latter respect, McIntyre J. blinds himself (at least temporarily) to the reality that judges are not merely neutral arbiters, passively accepting the law as they find it, but rather they do play a role in shaping and developing the rules they are asked to apply. The contrary position hardly 
seems arguable. Indeed, McIntyre J.'s selective blindness is lifted later in his judgment where he adjures the courts to develop the common law in light of the rights and freedoms guaranteed by the Charter. A more glaring contradiction is hard to imagine. McIntyre J.'s ruling effectively removes the common law from the ken of the courts, retroactively necessitating a kind of judicial immaculate conception.

Professor Beatty contends that the Supreme Court of Canada has neatly appropriated a considerable coercive authority to itself, indeed, to courts in general. Given that McIntyre J. accepts the all-encompassing words of s. 52(1) as embracing the common law, Beatty argues, it is not possible for him to hold that the base majority of judge-made law is exempt from Charter review. His decision "allows for the exercise of coercive legal authority by a group of unelected individuals in ways which may be completely at odds with the values which are constitutive of the political character of our community" 39 and furthermore, that it "will act as a cancer on the moral authority on which the very life of the judiciary depends"..$^{40}$ Although McIntyre requires the courts to develop the common law in light of the Charter, it is difficult to conceive how the courts can do this without a complete subjugation of the common law to the Charter. ${ }^{41}$

In the end, it is not clear what motivated the court's fear that the application of the Charter to the common law would immeasurably affect private litigation. Those who argue for wide-open application (including application to "private action") would see the "law" as including tacitly permissive law. If this argument were accepted, the Charter truly would be all-pervasive and any private act (of discrimination for example) to the extent that it was "permitted" because not clearly prohibited would be liable to attack under the Charter. However, if fear of such a result was behind the court's seemingly "knee-jerk" reaction, it could rather easily have limited the "law" to positive rules of law, whether statutory or common law. Ghislain Otis notes that
In the first place, positive rules of common law specifically mandating or proscribing private conduct in a manner contrary to the Charter would properly be invalidated . . . In cases where no such positive rule exists, it could be argued that "permissive" common law involves no governmental action even by the courts. It is by no means obviously logical that a mere judicial acknowledge- ment of an absence of legal prescription or prohibition automatically gives rise to a judicial infringement of the Constitution. ${ }^{42}$

Hogg is of a similar mind, in that a private actor does not enter the "public realm" until he seeks judicial enforcement of his act. Realistically, there is no "state" involvement in merely acknowledging the freedom of an individual. ${ }^{43}$

39. D. Beatty, "Constitutional Conceits: The Coercive Authority of Courts", (1987) 37 U. of T. L.J. 183 at 190.

40. Id. at 191.

41. Slattery suggests that the test the court would apply in developing and applying the common law in accordance with the Charter must ultimately be the test set out in $R$. v. Oakes [1986] 1 S.C.R. 103, 26 D.L.R. (4th) 200: see B. Slattery, “The Charter's Relevance to Private Litigation: Does Dolphin Deliver?" (1987) 32 McGill L.J. 905 at 920-21. I would add that, while this may be so, the remedy would be different as the court could not declare the common law nule to be of no force or effect. It could, however, decline to apply the rule in the particular case before it if to apply it would not produce a result consistent with the values enshrined in the Charter. On this point, see the discussion of the Coates case, infra.

42. Supra n.11 at 88.

43. See Hogg, supra n.3 at 678 ; and supra n.31 at 276 . Otis puts it as follows: “Only by a quite unusual fiction would the court itself become the author of that particular conduct merely by stating that the law does not prohibit it" (Supra n.11 at 89). 
Fortifying the restriction of the Charter only to positive rules of law is the problem of a remedy were a "permissive" law declared unconstitutional. If a permissive aspect of a statute were found unconstitutional, arguably the entire piece of legislation could be declared of no force or effect. However, such a result could prove extremely disruptive. The only other alternative (indeed, the only alternative where a permissive common law rule is involved) would be to force legislative action to correct the "unconstitutional freedom." It is unlikely that such a result is defensible, so that the Supreme Court of Canada would be well-justified in limiting Charter application to positive rules of statutory or common law.

\section{A Fresh Perspective}

The basic error underlying McIntyre J.'s reasoning appears to be his assumption that all private "activity" would be caught by the Charter if the common law in whole were subject to constitutional review. Given his conclusion that the Charter applies only to government activity, His Lordship denies that the common law is government activity merely because it is "judicial legislation". However, it is far from clear that, even if the courts were considered to be part of the "government" within the meaning of s. 32(1), all private activity would be caught.

Conceiving a spectrum of Charter application, we immediately see that a large chunk of private activity is immune from review, even if the judiciary is considered a branch of government. At the end of the spectrum representing the clearest case of Charter application are found statutory prohibitions and permissions, or other "governmental" acts, the latter meaning acts of the executive branch of government. Included under this classification are cases of direct review of legislation, e.g. Ref. re Section 94(2) of the Motor Vehicle Act, R.S.B.C. 1979, c. $288,{ }^{44}$ cases of review of legislation in the context of private litigation, e.g. Re Blainey and Ontario Hockey Association, ${ }^{45}$ and cases of review of other governmental "acts", e.g. Operation Dismantle v. The Queen. ${ }^{46}$

Further along the spectrum are encountered rules purely of the common law, yet which are facially contrary to the provisions of the Charter. Arguably, Dolphin Delivery involved such a rule since the principle that secondary picketing constituted the tort of inducing breach of contract was, on its face, violative of s. 2(b), freedom of expression. A clearer case is that of New York Times v. Sullivan ${ }^{47}$ in which a newspaper had published material that was critical of a public official, who sought damages in defamation, a purely common law tort. The United States Supreme Court said that the First Amendment guarantee of "freedom of the press" required that the common law tort of defamation be limited by a defence of "qualified privilege" so that to establish defamation, the public official would have to prove "actual malice" in the publication of the material in question. In the result, because the official was unable to prove such malice, the damage award was quashed. Thus, the American Bill of Rights applied directly to modify a common law rule that had application in a dispute between the two parties.

44. [1986] 1 W.W.R. 481, 63 N.R. 266 (S.C.C.).

45. Supra n.35.

46. Supra n.12.

47. (1963) 376 U.S. 254. 
The third and perhaps most controversial point on this spectrum is that representing a facially neutral common law rule that is applied or enforced by the court in a manner contrary to Charter rights and freedoms. Again, the best example is from the United States, in Shelley v. Kraemer, ${ }^{48}$ which involved a dispute (between purely private parties) arising out of a racially discriminatory restrictive covenant. Landowners adjoining another who had breached the covenant sought and obtained an injunction to prevent the sale of the land to a black person. The United States Supreme Court held that the court's order to enforce the restrictive covenant amounted to an order to discriminate on racial grounds. There was no statute involved, merely the common law power of the courts to enforce restrictive covenants by way of injunction. The application of this rule was thus held to be unconstitutional under the American Bill of Rights. ${ }^{49}$ Harking back to the discussion of law and freedom, we can see that the action of the landowners in creating the restrictive covenant was action pursuant to a "freedom" because the rules relating to restrictive covenants did not contain any express permission or prohibition of racially discriminatory covenants. As a result, without more, the covenant would be effectively immune from constitutional review. It is only when the parties engage the Courts to enforce the covenant that the constitution comes into play. In fact, the covenant itself is, it would appear, still immune, but the remedy associated with it is subject to scrutiny, and in Shelley, the remedy was found to be unconstitutionally discriminatory. The availability of court enforcement thus empties the "freedom" of its substance.

There may be a theoretical difficulty when dealing with instances of these second two types of review, in that we must decide what type of constitutional remedy is being sought. Where a challenge is made to a rule of law, be it statutory or common law facially contrary to the Charter, a declaration of no force and effect is available pursuant to s. 52(1). Where, however, it is a governmental act that is challenged, including the act of judicial enforcement, then no declaration will be available under s. 52(1), and the party making the challenge will be restricted to his s. 24(1) remedies. Thus, in a Shelley-type case, the remedy would be refusal to enforce the covenant. However, it would seem that the effect of the remedy in such a case is a modification of the common law rule itself since the freedom to create restrictive covenants would have carved out of it the ability to create a meaningful, racially discriminatory, restrictive covenant.

Even if the Supreme Court of Canada had wished to restrict the application of the Charter to facially discriminatory common law rules, it could have done so on a somewhat rational basis. There is an argument to be made, of course, that positive rules of the common law (those expressly or by necessary implication prohibiting or permitting activity) are essentially analogous to legislative provisions and therefore ought to fall under the scrutiny of the Charter. On the other hand, where the court is asked to enforce a facially neutral rule, there is no similar analogy with legislative action: the court is, in fact, being asked to enforce a freedom, and there-

48. (1948) 334 U.S. 1.

49. The United States Supreme Court actually based its decision on the "state action" doctrine, holding that the action of the court was supported by "the full panoply of state power" (Id. at 19) and therefore was subject to the Bill of Rights. 
[VOL. XXVII, NO. 3

fore the Charter should not apply in such instances. ${ }^{50}$ The difficulty with this approach is that if we accept positive rules of the common law as evidencing government action, then why should we not also recognize court enforcement of facially neutral rules that contravene the Charter?

At the other end of the spectrum along which we have been meandering, are found those instances of purely private acts that cannot be reached by the Charter. Here are all of those "freedoms" pursuant to which most of our daily activities are carried out, including, for example, denying a tenancy to someone of whom we disapprove. While there may be human rights remedies for such acts, there are no direct constitutional remedies. ${ }^{51}$ The most important point to note, however, is that this block of private activity is immune from Charter examination despite the characterization of the courts as government. The reason for this immunity is that the courts are not involved in such private acts so that the characterization of the court system as a branch of government in no way colours this sphere of private behaviour.

The result of McIntyre J.'s unfortunate decision is that out of fear of catching activity that would, in fact, be immune, the Supreme Court of Canada has also immunized positive rules of law and court activity that may have as deleterious an effect on our rights and freedoms as passage of any statutory provision. While it was open to the court to take a principled, and reasoned approach to the issue before it, the court instead entered a judicial netherland, ultimately leaving us to grope for rational explanations. Similarly, we are left to scramble for creative solutions to the problem of subjecting rules of the common law to Charter scrutiny where, on the surface, at least, there is no appearance of governmental action. The evidence of this scramble is already emerging from the Charter cases decided post-Dolphin.

\section{THE FALLOUT}

The clear consequence of Dolphin Delivery is that unless one can point to a legislative provision governing the relationship of the private litigants, or upon which one of the litigants bases his action, one will have to prove either that the other party has some nexus with government such that the party's action can be considered governmental, or that the party relies on some governmental action, other than a strictly legislative one, to support the infringement of a Charter right.

The Supreme Court of Canada in Dolphin Delivery provided little guidance in this respect, saying only that " $[t]$ he element of governmental intervention necessary to make the Charter applicable in an otherwise private action is difficult to

50. There is the somewhat sophistical argument that the first time a facially neutral rule is sought to be enforced in a particular way (i.e. in the absence of judicial precedent) there is no governmental act until the court renders judgment enforcing the rule in that way, and thereby creating a precedent. Future cases seeking similar enforcement could then attract the Charter because there would be a positive common law nule to which it could apply. However, this argument generates rather hair-raising philosophical questions about stare decisis and legal realism, among others.

51. Note further that the Supreme Court of Canada has already held, in Seneca College v. Bhadauria [1981] 2 S.C.R. 181, 124 D.L.R. (3d) 193, 14 B.L.R. 157, that there can be no action for damages for " human rights torts" under provincial human rights legislation. It is unlikely that the Supreme Court would agree to such a concept under the Charter. Indeed, this much appears clear from Dolphin Delivery. 
define", ${ }^{2}$ and later that "it is difficult and probably dangerous to attempt to define with narrow precision that element of governmental intervention which will suffice to permit reliance on the Charter by private litigants in private litigation".${ }^{33}$ McIntyre J. was prepared to suggest that the Charter might apply to delegated legislation, including municipal by-laws, and possibly to by-laws and regulations of other "creatures of Parliament and the legislatures". ${ }^{44}$ These vague hints, therefore, leave the field rather gapingly open.

It is a field into which one hesitates to tread, and indeed, one which is beyond the scope of this paper. If more than 100 years of American jurisprudence, and the development of the "state action" doctrine, have taught us anything, it must be that we can expect a case-by-case approach, possibly leading to inconsistent results. Professor Gibson has pointed to this threat as a reason not to distinguish between public and private action..$^{55}$ However, it seems unlikely that the line will be drawn precisely where he would see it drawn: it is fairly well-established that the Charter regulates the relationship between government and citizen, and not between citizen and citizen - at least, not directly. Therefore, we are left to argue for two things: 1) An expansive view of the term "government" to catch all "state action" that is not based merely on the "freedoms" that we find within the cracks in our law (either statutory or common law); and 2) An expansive view of "government action" in order to bring the positive rules of the common law within the reach of the Charter.

\section{A. THE MEANING OF "GOVERNMENT"}

Already developing is a body of jurisprudence concerning the meaning of the term "government" and what entities may be classed thereunder, a detailed discussion of which is beyond the scope of this article. Many of these cases deal with terms of collective agreements, or mandatory retirement clauses in employment contracts. Many of them also take a rather formalistic view of "government", which is consistent with the approach that seems to underlie McIntyre J.'s decision

52. Supra n.1 at 195.

53. Id.

54. Id. at 198.

55. See esp. "Distinguishing the Governors from the Governed," supra n.4. 
in Dolphin Delivery. ${ }^{56}$ Others ${ }^{57}$ suggest a "functionalist alternative" (to use the terminology of Robert Howse ${ }^{s 8}$ ) which eschews the formalistic approach in favour of a more "substantial" one. In the words of Howse,

even though a violation of rights involves no formal government activity, from the perspective of Charter values it may be equivalent to a violation by acts of government. This would not be to overrule the principle that some public element must be present for the Charter to apply but rather to employ that principle in a functional, rather than a formalistic manner. ${ }^{59}$

Where one party in an apparently private dispute alleges an infringement by the other party of his Charter rights, it would, therefore, be open to the first party to argue that, although there is no formal connection with government, yet the second party infringing his right must be taken to have acted functionally as though that second party were government. ${ }^{60}$

A related alternative, which approaches the problem from the other end, is promulgated by Professors Slattery ${ }^{61}$ and Buckingham. ${ }^{62}$ Their "purposive approach" proceeds from the premise that the question of whether the Charter applies in toto to private action is ultimately unanswerable. Instead, the court must analyze each case individually, asking itself what the purpose of the infringed

56. E.g., Lavigne v. Ontario Public Service Employees' Union (1986) 29 D.L.R. (4th) 321 (Ont. H.C.) (statutory authority to collect dues could lead to indirect challenge of union's use of dues provided that governmental nexus exists); Re Tomen and Federation of Women Teachers' Association of Ontario (1987) 61 O.R. (2d) 489 (H.C.) (by-law of Ontario Teachers' Federation not subject to direct Charter scrutiny because the by-law could be changed by vote of membership. As such it was merely a private matter and could not be considered govemmental activity); Re Ontario English Catholic Teachers Assn. and Essex County Roman Catholic Separate School Board (1987) 36 D.L.R. (4th) 115 (Ont. Div. Ct.) (mere fact that contracting party has nexus with govemment will not necessarily attract Charter); $M c K i n$ ney v. Liberal Party of Canada (1987) 21 C.P.C. (2d) 118 (Ont. H.C.) (Charter not applying to unincorporated political party as discipline of members not a governmental act).

57. E.g., R. v. Lerke (1986) 25 D.L.R. (4th) 403 (Alta. C.A.) where a tavem manager and his employees, who searched a young person returning to the tavern after having been asked to leave, were held to be exercising a public function and, therefore, their actions were subject to Charter review under s.8 (unreasonable search and seizure). In the opinion of Laycraft C.J.A., at 406: "the arrest of a citizen is a governmental function whether the person making the arrest is a peace officer or a private citizen" [emphasis added].

Professors McLellan and Elman suggest that the Court of Appeal may have been aided in reaching this conclusion in that, under s.98(3) of the Liquor Control ACt, R.S.A. 1980, c.L-17, under which Lerke was initially charged, a person asked to leave a tavern who does not do so is trespassing. In addition, a power of arrest is given to an owner of land and his servants under the Petty Trespass Act, R.S.A. 1980, c.P-6, s.4. Thus, there was some "statutory background" for the actions of the tavem manager and his employees.

See also McKinney v. University of Guelph (1988) 46 D.L.R. (4th) 193 (Ont. C.A.), leave to appeal to S.C.C. granted 2 April 1988 (Universities not government because they are autonomous bodies administered privately by Board of Governors. Public funding not a determinative issue. Therefore, mandatory retirement policies of universities not directly subject to Charter review); Harrison v. University of B.C. (1988) 21 B.C.L.R. (2d) 145 (C.A.) (same approach as in McKinney v. University of Guelph).

58. R. Howse, "Dolphin Delivery: the Supreme Court and the Public/Private Distinction in Canadian Constitutional Law", (1988) 46 U. of T., Fac. of L. Rev. 248.

59. Id. at 253.

60. Early support for a more functional approach can be found in Re Klein and Law Society of Upper Canada (1985) 16 D.L.R. (4th) 489, 50 O.R. (2d) 118, 13 C.R.R. 120, in which Law Society regulations were held subject to the Charter because regulation of legal practitioners was considered to have a "public dimension".

61. Supra n.6.

62. Supra n.5. 
Charter right is, and whether the infringement by a private actor significantly interferes with that purpose. This approach is consonant with the test set out in $R$. v. Oakes. ${ }^{63}$ Its drawback is that it would seem to require all private acts of Charter infringement to be put in the Constitutional balance, a result that we should attempt to avoid.

\section{B. THE MEANING OF GOVERNMENT “ACTION”}

Not only are there many manifestations of "government", some traditional and some less so, there are also many potential forms of government action attracting the constitutional offensive. Those forms emerging both prior and subsequently to Dolphin Delivery are discussed in detail below.

\section{Omission}

In Hoogbruin v. A. -G. B.C. ${ }^{64}$ a decision of the British Columbia Court of Appeal, Hoogbruin sought a declaration that s.2(1) of the Election Act ${ }^{65}$ was contrary to his Charter "right to vote". Although s.2(1) provided that there was an entitlement to vote in any provincial election, it contained no mechanism for absentee voting. Hoogbruin, who was in Ontario when the election occurred, had contacted the Deputy Registrar of Voters in British Columbia and was told that he would have to attend a poll in B.C. if he wished to vote and was thus unable to vote in the election. The Court of Appeal granted the declaration, being of the opinion that

it matters little whether the individual is deprived of the substance of the right to vote by commission (an express statutory limitation) or by omission (the failure of the statute to provide a mechanism to vote and thus creating a limitation to the right to vote). ${ }^{66}$

[A]lthough s.2(1) of the Election Act of British Columbia states that these appellants have an entitlement to vote, by failing to provide a mechanism to implement that right, the statute has deprived them of the substance of that right and thus infringed their Charter right to vote. ${ }^{67}$

The Court of Appeal struggled with the remedy it should grant in the circumstances, finally deciding that it would merely declare the omission to be inconsistent with the Charter and therefore of no force and effect. This result is extremely important in two respects: 1) It adds force to the suggestion that "tacit permissions" or freedoms are "law" since only "laws" can be declared of no force or effect under s.52(1); and 2) A government may be forced into legislative action where it omits to do something in an unconstitutional way, as well as where it commits something unconstitutional.

As yet, there do not appear to be any other reported cases finding an unconstitutional omission, and it would be the author's guess that if the Supreme Court of Canada had the opportunity, it would overrule any such trend. It is not obvious that the decision in Hoogbruin is vitiated by Dolphin Delivery alone. It may be, however, that the case is explainable in more orthodox terms, those more clearly

63. Supra $\mathrm{n.41}$.

64. (1986) 24 D.L.R. (4th) 718, [1986] 2 W.W.R. 700, 70 B.C.L.R. l. All references are to 24 D.L.R. (4th).

65. R.S.B.C. 1979, c. 103 .

66. Supra n.64 at 720.

67. Id. at 721. 
consistent with Dolphin Delivery, namely, that the plaintiff was a victim of a blatant governmental denial of his right to vote, in the guise of the Deputy Registrar's counsel that Hoogbruin could not vote in absentia. Although the statute contained no provision either permitting or denying such a process, the Deputy Registrar acted positively in denying Hoogbruin an absentee vote. Therein lay the governmental act. Of course, there is no suggestion in the reasons of the Court that this approach was taken by it, and the remedy ultimately granted militates against it.

Hoogbruin was sought to be applied in Baldwin v. British Columbia Government Employees Union, ${ }^{68}$ a case in which it was argued that a private actor exercises a governmental power when it acts under implied statutory authority. Although not a member of the respondent union, the petitioner was required by provincial legislation, as a member of the bargaining unit, to pay dues. Petitioner sought a declaration that the union's use of dues for purposes unrelated to collective bargaining violated ss.2(a), 2(b), 2(d), and 7 of the Charter, and alternatively that s. 14 of the Public Service Labour Relations Act, ${ }^{69}$ which empowered the union to collect dues without specifying how they were to be used, was contrary to the Charter, and in the second alternative, for a declaration that the government's agreeing to allow collection of union dues without ensuring the use of these dues was proper, violated the Charter.

Mackoff J. of the British Columbia Supreme Court distinguished Hoogbruin on the basis that in the latter case, a statute was under direct attack, and it was the statute itself that infringed the right and not the act of someone else as was alleged in Baldwin. It was the view of the court that where the statute, as here, does not give or take away an entitlement, a declaration would issue only if the actor allegedly infringing the right could be considered governmental. What the court seems to be saying is that "impliedly permissive" aspects of the law will be subject to Charter scrutiny provided the entity that acts pursuant to that "permission" falls within the meaning of government. ${ }^{70}$ On the facts of the case, the Court could not find that the union was exercising any government function: it could not be said to do so merely by acting pursuant to an implied permission. The expenditure of collected dues was a matter of a private nature, being merely a part of the union's constitution, and did not require "any positive action by the government to breathe life into

68. (1986) 3 B.C.L.R. (2d) 242, [1986] 4 W.W.R. 679 (S.C.). All references are to 3 B.C.L.R. (2d).

69. R.S.B.C. 1979, c. 346 .

70. There is some suggestion of this approach in Lavigne v. Ontario Public Service Employees' Union, supra, note 56, where it was held that statutory authorization of a union to collect dues from non-members could lead to an indirect challenge on the use of those dues provided that there was the requisite element of government action. The court distinguished Baldwin, but the decision seemed to tum on the finding that the employer, the Ontario Council of Regents for Colleges of Applied Arts and Technology, was a govermment actor. The author is at a loss to explain the difference between this case and Baldwin if this is the key factor, since the employer in Baldwin was also the government. In any event, the author fails to see how the nature of the employer has any relevance in these cases since it is the act of the union in collecting and spending dues that is impugned, not an act of the employer. 
[it]" ". Since the party was private and the matter complained of was not one which occurred in the exercise of the very power authorized by the statute (the petitioner was not challenging the right of the union to collect dues), the Charter had no application.

It is difficult, in fact, to distinguish Baldwin and Hoogbruin, unless one accepts the "governmental act" hypothesis offered above to explain the latter case. In both cases, what was complained about in relation to the statute in question was an omission: in Hoogbruin, the failure to provide absentee voting procedures; in Baldwin, the failure to control the expenditure of dues by the union. The only difference seems to be that in the former there is a closer connection with government because the Deputy Registrar, a governmental actor presumably, was interposed, whereas in the latter, it was the union, a non-governmental actor, spending the dues in the manner offensive to Baldwin. Mackoff J.'s suggestion that the statute in Hoogbruin was under direct attack rings hollow when it is considered that the statute in Baldwin authorizing collection of dues then failed to control their expenditure. ${ }^{72}$

\section{The "Administration of Justice" Cases}

While Dolphin Delivery seemed to scotch the notion that the courts are a branch of government for Charter purposes, cases decided both before and after it have suggested otherwise. That is, these cases at least intimate that the courts are bound strictly by the Charter, and not in the more diffuse sense proffered by McIntyre J.

Prior to Dolphin Delivery, the Supreme Court of Canada had the opportunity to assess the activities of the courts in light of the Constitution in Dubois v. The Queen. ${ }^{73}$ Although not cited in Dolphin, nor apparently considered by the Supreme Court in that case, Dubois dealt directly with the application of the Charter to the courts. The accused had appealed his conviction for second degree murder and successfully obtained a new trial. However, the second trial judge admitted the testimony of the accused given at the first trial, against the objection of the accused that his right to avoid self-incrimination under s. 13 of the Charter was violated. The Supreme Court of Canada agreed that the evidence was inadmissible.

The importance of the case lies in its apparent acceptance that a court decision is subject to full-blown Charter review. There was no statutory provision at issue, and no governmental actor, merely a ruling by a court having the effect of denying the rights of the accused. Since the Supreme Court failed to articulate the basis on which it rested its conclusion, it may not be entirely correct to assume that it viewed the court system as "government". Instead, the Court may have looked to the language of s.13 and related rights to find that the courts are clearly contemplated as being bound by those sections. However, if s.32 is the overriding section, and if we have assumed that it embraces only government action, then the Supreme Court must be assuming the courts are "government". If the courts are government in relation to some rights enunciated in the Charter, are we not drawn ineluctably to the conclusion that the courts are government simpliciter? If a court

71. Supra, note 68 , at 251. According to Mackoff J., at 251:

72. There is, however, yet another possible explanation of the Hoogbruin decision, and it is discussed in connection with the Coates case, infra.

73. [1985] 2 S.C.R. 350 . 
order or ruling is government activity in relation to one right, why not in relation to all? $?^{74}$

The Supreme Court of Canada was faced with a similar problem in $R$. v. Rahey ${ }^{75}$ heard prior to Dolphin Delivery, but judgment was not rendered until some time later. The case involved a person charged with filing false and deceptive tax returns, but whose trial was inordinately delayed due to repeated adjournments. The most telling passage in the judgment is contained in the reasons of Mr. Justice LaForest, where he says:

Quite apart from what may be gleaned from a parsing of the language of s.11(b) and analogous provisions, however, it seems obvious to me that the courts, as custodians of the principles enshrined in the Charter, must themselves be subject to Charter scrutiny in the administration of their duties. In my view, the fact that the delay in this case was caused by the judge himself makes it all the more unacceptable both to the accused and to society in general. It would be a cold comfort to an accused to be brought promptly to trial if the trial itself might be indefinitely prolonged by the judge. ${ }^{76}$

Not only does this approach seem to fly in the face of the same Court's reasons in Dolphin Delivery, but McIntyre J. having written the majority reasons in that case also concurred in the reasons of LaForest J. in Rahey! ${ }^{77}$

Dolphin and Rahey are not, however, completely irreconcilable. Rahey potentially creates an exception to the Dolphin rule that the courts are not governmental actors, where the alleged infringement of a Charter right arises from the administration of justice by the courts. The analogy is similar to that in the "governmental actor" cases where, for example, the same Crown Corporation is said to be acting governmentally in some situations, but not in others. The analogy is not, however, without imperfections.

An extension of this "administration of justice" argument presents itself if we consider the arsenal of enforcement procedures available to a successful litigant. Even if the initial court order enforcing either a facially neutral or facially contrary rule of the common law cannot properly be called government action, nevertheless, at some point in the enforcement process, there may be a sufficient nexus with the state to ground Charter review. For instance, imprisonment for contempt imposed for failing to obey the original court order may represent sufficient government action to attract the protection of the Charter. ${ }^{78}$

\section{Direct Application to Positive Rules of the Common Law}

Although McIntyre J. rejected the proposition that the common law can be subjected wholesale to constitutional review, he nevertheless suggested that where the party seeking to challenge a common law rule can show a sufficient nexus between the rule and government, the rule must meet strict Charter standards. Unfortunately, the Court failed to offer any sort of hint as to the nature of this nexus.

74. Interestingly enough, McIntyre J. dissented in the case, but only on the basis that the second trial did not fall within the meaning of "proceedings" in s.13.

75. [1987] 1 S.C.R. 588 .

76. Id. at 633 .

77. The Court was unanimous in holding that the accused's right to trial within a reasonable time had been violated.

78. A case at least partly on point is $R$. v. Kopyto (1988) 24 O.A.C. 81 . Since it is the author's view that this case is decided on a somewhat different footing, it is discussed more fully below. 
McBeth v. Governors of Dalhousie College $e^{79}$ was decided a few months before Dolphin Delivery and represents perhaps the "ideal" approach to a positive rule of the common law. McBeth was a university student who brought a breach of contract action against the university for failing to schedule a supplemental exam after she had missed the regular exam due to illness.

She successfully recovered damages, but was refused costs on the basis that she had appeared in person at the trial, rather than through her solicitor. The Nova Scotia Court of Appeal accepted that there were no statutory prohibitions against awarding costs to a successful litigant in person, merely a long-standing common law rule. Without addressing the question of the application of the Charter to the common law, the court, speaking through Morrison J.A., concluded that the practice was clearly discriminatory and violated s.15, and furthermore, was not a reasonable limit under s.1. In awarding a remedy His Lordship said:

There is no existing statute to declare inoperative; however, I conclude that the practice should be discontinued and that the successful unrepresented litigant should be awarded his or her costs the same as a litigant who is represented by counsel. 80

Representing, as it does, the strict approach to the constitutionalization of the common law, McBeth is no doubt overruled by Dolphin Delivery. But if Dolphin creates a gap, it has only served to entice both ingenious lawyers and ingenious judges into valiant attempts to span it.

Bartello v. Canada Post Corporation ${ }^{82}$ is not a clear example of the Charter's application to the common law, but it is quite consistent with the decision in Dolphin and yet may support the extension of Charter review to certain parts of the common law. The plaintiff was a member of the Letter Carriers Union of Canada, which had a collective agreement with the employer, Canada Post, and was discharged from his employment. He brought a grievance, but the union elected not to proceed to arbitration pursuant to an arbitration clause in the collective agreement (the Canada Labour Code $e^{83}$ required every collective agreement to contain a binding dispute resolution mechanism). As a result, the plaintiff brought a common law action for wrongful dismissal. When Canada Post moved to strike out the statement of claim, the plaintiff conceded that he could not maintain the action at common law because of a long line of judicial authority holding that the right to bring an action for wrongful dismissal is extinguished when the employment relationship is governed by a collective agreement. However, the plaintiff contended that this extinguishment of his common law right of action was contrary to $\mathrm{s.15}$ of the Charter. The plaintiff also sought a declaration that s.155 of the Canada Labour Code violated the Charter.

The court, consisting of Henry J., identified three subsidiary issues:

1) Could the Charter apply to the collective agreement between Canada Post and the Letter Carriers Union of Canada?

2) Does the Charter apply to s.155 of the Canada Labour Code?

3) Does the Charter apply to the common law principle that extinguishes plaintiff's right of action to sue for wrongful dismissal?

79. (1986) 26 D.L.R. (4th) 321 (N.S.C.A.).

80. Id. at 330.

81. McBeth may, however, be consistent with McIntyre J.'s "lifeline", which is discussed below.

82. (1988) 46 D.L.R. (4th) 129, 18 C.C.E.L. 26 (Ont. H.C.). All references are to 46 D.L.R. (4th).

83. R.S.C. 1970, c.L-1, s.155, am. 1977-78, c.27, s.52. 
The court answered the first question in the negative. Although Canada Post is made an agent of Her Majesty by s.22 of the Canada Post Corporation Act, ${ }^{84}$ and in that respect is a part of the executive branch of government and therefore attracts the Charter to some extent, yet the court felt the nature of the contract between Canada Post and the union to be a private matter, beyond the reach of the Charter. Henry J. approved of Professor Swinton's comment that

[t]he govemment's forays into commercial activity should not, however, automatically be subject to the guarantees of the Charter. The statutes which may create such entities are, of course, open to scrutiny, but the corporate activities of the Crown corporations will rarely, if ever, fall within the scope of "governmental" action against which the Charter is directed.s

He also adopted the Ontario Divisional Court's ruling in Re Ontario English Catholic Teachers Assn. and Essex County Roman Catholic Separate School Board $^{86}$ that the mere fact that a contracting party has a nexus with government will not attract the Charter.

However, Henry J. went on to apply the Charter to s. 155 of the Canada Labour Code, which requires every collective agreement to contain a binding dispute resolution mechanism. The plaintiff's concession that his action at common law for wrongful dismissal must fail had its basis in a long line of cases holding that once an employment relationship is governed by a collective agreement, the common law is no longer relevant to the extent that relations are so governed. This principle was recognized by the Supreme Court of Canada in McGavin Toastmaster Ltd. v. Ainscough ${ }^{87}$ The court in Bartello adopted the statement of the principle as set out in an Ontario Divisional Court decision, Bergeron v. Kingsway Transports Ltd.: ${ }^{88}$

Because of the contractual provisions for final settlement of all differences by arbitration and the privative clause protecting the decision of any arbitrators who might be called to resolve any such differences, we are of the opinion that a Court has no right to consider the issues raised in this case notwithstanding the fact that the plaintiffs have exhausted the remedies provided in the collective agreement.

Henry J. considered that the Charter must apply to a statute passed by Parliament. Here, the Canada Labour Code required a person to accept a particular contractual provision and Henry J. was prepared to subject s. 155 to a Charter analysis. He did so and concluded that if s.155 did violate the Charter, it was a reasonable limit under s.1.

The interesting point to note about Henry J.'s analysis is that on its face, s. 155 probably would not have infringed the Charter. It was only the common law background against which $\mathrm{s} .155$ was cast that led to the extinguishment of the right of

84. S.C. $1980-81-82-83$, c. 54 .

85. Supra n.3 at 59. There is, however, a decision of the Ontario Court of Appeal, Roy v. Hackett (1988) 45 D.L.R. (4th) 415 , which seems to mitigate some of Henry J.'s decision in Bartello on this point. In Roy, Lacourciere J.A. indicated a preference for the view that all actions of "governmental agents" should be subject to Charter review, not merely "govemmental acts". The case concerned a common law rule of evidence, giving discretion to the arbitration board to allow cross-examination of Roy with respect to his need for an interpreter even after the interpreter had been granted, which Roy alleged violated his right to an interpreter under s. 14 of the Charter. Lacourcière J.A. would have applied the Charter to the rule of common law because he felt the employer, as a government agent, was relying on it, but in the circumstances, he did not consider that Roy's right under s.14 had been infringed.

86. Supra n.56.

87. (1975) 54 D.L.R. (3d) 1, [1976] 1 S.C.R. 718, [1975] 5 W.W.R. 444. See especially Laskin C.J.C.'s words in 54 D.L.R. (3d) at 5-6.

88. (1979) 79 D.L.R. (3d) 749 at 752. 
action which Bartello claimed was a violation of his rights. Henry J. only hints, however, that he is taking this approach, and he does so only twice. Firstly, in summarizing the position of counsel for the plaintiff, he says of s.155:

[T] hese provisions . . . are those which require the parties to the collective agreement to provide for resolution of disputes (by arbitration or otherwise) within the framework of the collective agreement, and by implication, not by recourse to common law action in the courts9 [emphasis added].

Secondly, he says, in deciding whether the Charter applies to s.155:

Moreover, the statute by s. 155 imposes on the parties the obligation to provide for the final resolution of disputes, and if the parties do not agree to that, or do not implement the principle, the statute requires submission to arbitration and imposes a procedure. In this context the common law cause of action against the employer is extinguished so far as the employees covered by the collective agreement are concemed ${ }^{90}$ [emphasis added].

The conclusion one may seek to draw from this case is that where the existence of a common law rule has the effect, in combination with a statutory provision, of denying a Charter right, then the courts may be willing, under the guise of attacking the statute, to scrutinize the whole statute/common law relationship in light of the Charter. Thus, an indirect attack can be made on the common law by locating the requisite "governmental nexus" in a statute that, on its face might not infringe the Charter, but in connection with the common law rule, clearly does.

Bartello may represent the way in which judicial interpretation of statutory provisions can be subjected to the Charter. That is, where there is an otherwise facially neutral legislative enactment, but the courts have interpreted it in a manner contrary to the Charter, a litigant may have a Charter remedy. Although it is the statutory provision that is declared unconstitutional, nevertheless, the common law interpretation is rendered ineffective because it no longer has anything on which to operate. When the offending provision is removed, its interpretation is impotent.

A case which takes the next step along this narrow path is a recent decision of the Trial Division of the Supreme Court of Nova Scotia. In Coates v. The Citizen, ${ }^{91}$ a newspaper was faced with a libel action by a prominent politician. The Defamation $A C^{22}$ of Nova Scotia was relied on by The Citizen as showing "clear statutory adoption, modification or preservation of the common law relating to libel and slander as the law for the province of Nova Scotia". ${ }^{93}$ That is, The Citizen relied on both the explicit and implicit "legislative dimensions" of the Defamation Act. The examples of "implicit legislation" relied on by The Citizen were quite numerous, but one should suffice to illustrate the nature of the newspaper's argument: s. 1(b) of the Act defines defamation to mean libel or slander, "thereby adopting the common law meaning of those words and the elements of those causes of action". ${ }^{94}$ The position of The Citizen was fortified by explicit adoption of various parts of the common law into the statutory scheme. The result of this legislative activity was to make it clear that "the legislature has considered, and through the $A c t$, adopted, modified, or preserved each aspect of the common law which the Applicant now claims is unconstitutional"'. ${ }^{95}$ In addition, it was felt that the
89. Supra $\mathrm{n} .82$ at 137.
90. Id. at 143-144.
91. Unreported, 12 May 1988, J.D. of Halifax.
92. R.S.N.S. 1967, c.72.
93. Memorandum of counsel for The Citizen, at 41.
94. Id. at 42.
95. Id. at 45 . 
Judicature Act, ${ }^{96}$ which required the Supreme Court of Nova Scotia to apply the rules of the common law, strengthened the governmental nexus. Counsel for The Citizen summarized its position as follows:

Due to the implicit and explicit statutory adoption, modification or preservation of common law defamation rules in the Defamation Act and the statutory obligation contained in the Judicature Act to administer those rules, the Charter applies to the law under challenge herein. This is consistent with the recent decision in Dolphin Delivery. In that case, the Supreme Court stated that it was difficult to define the elements of govemmental intervention necessary to make the Charter applicable and that it was dangerous to attempt to do so with narrow precision. The Court framed the question by asking:

... does the Charter apply to private litigation divorced completely from any connec-

tion with Government?

Far from being completely divorced from any government connection, the present case involves legislative approval of defamation actions against newspapers and express legislative adoption and approval of unconstitutional elements of defamation law. In addition, the legislature of Nova Scotia has, through the Judicature Act, specifically directed the Court to apply those rules. The present case is completely different from the situation in Dolphin Delivery, where it was noted that no statute was involved.97

In fact, this argument was accepted (or at least it appeared to be) by Richard J. in his decision at trial. He acknowledged that the dispute was one between private parties and the law relied on was mixed common law and statute, therefore to the extent that The Citizen was impugning a common law rule, it had to show a sufficient governmental nexus to satisfy the rule set out in Dolphin Delivery. His pivotal ruling is contained in the following passage:

In this action we have the contention that the Defamation Act, a provincial statute, is contrary to the Charter in that it militates against freedom of the press. The Citizen contends that it must be struck down as being of "no force and effect". I find that the Defamation Act, being a provincial statute does provide that connection necessary to allow application of the Charter to what otherwise is litigation between private parties. It is the $A C t$, and the common law which impose upon The Citizen the several "reverse onuses" complained of. . . . Both the $A c t$ and the common law are amenable to Charter supervision. I think it matters not that some of the common law principles are subsumed into the $A c t .{ }^{98}$

In the result, to the extent the common law principles of defamation could be connected with the legislative "act" evidenced by the Defamation Act, such principles would stand or fall in the face of the Charter. On the facts of the case, Richard J. could not find that the Defamation Act did infringe The Citizen's right under s.2(b) of the Charter.

Manwaring suggests that Dolphin Delivery might even have been decided on a basis similar to that apparently accepted by Richard J. in Coates. Manwaring says:

Most matters relating to collective bargaining are governed either directly, by the relevant labour relations statutes, or indirectly, by laws which define and limit the jurisdiction of the courts. When creating this elaborate regulatory system, our governments were well aware of the policy choices which they were making. The rules governing picketing were, and still are, controversial. A decision not to change a common law rule is as much a state action as the decision to change it.

96. S.N.S. 1972, c.2, ss.2, 3, 38(6).

97. Supra $\mathrm{n} .93$ at $47-48$.

98. Supra $\mathrm{n} .91$ at $18-19$.

99. The difficulty with the ruling is that, although Richard J. seemed to approve the argument of The Citizen that the Defamation Act in its wider sense - i.e. including all common law principles implicitly embraced by it - would be subject to Charrer scrutiny, in his s.2(b) analysis, Richard J. repeatedly refers only to the "Act", suggesting possibly that he really was not prepared to go so far as he initially indicated. Nevertheless, the express approval of The Citizen's argument is a valuable tool. 
Therefore, it seems reasonable to conclude that once a government decides to regulate an area of activity, it has an obligation to ensure that the regulatory system created, which is composed of statutory and common law rules, conforms to the Charter. The Charter may not impose any positive obligation to intervene. The legislatures could leave the common law intact. However, once they decide to intervene they should be required to take the Charter into account. It would be a curious result if legislatures could avoid their Charter obligations by simply leaving in place judge-made rules which infringe the Charter while regulating the remaining areas of activity. ${ }^{100}$

Put in its simplest form, the proposition made by both The Citizen and Manwaring is that where the government adopts a scheme that is partly statutory and partly common law, modifying the common law and leaving portions of it intact, or merely adopting common law provisions (effectively) by references, then, as long as it can be shown that government has considered the common law and has made some sort of conscious choice toward it, then the common law rules that form part of the scheme will be subject to the Charter. The proposition really amounts to a kind of "tacit legislation" and involves "piggybacking" the common law onto related statutory provisions in such a way as to demonstrate an implicit, or explicit, approval of the common law part of the scheme on the part of the government. Arguably, there is sufficient governmental action to bring both the legislative provisions and the common law within the ambit of the Charter.

The Coates-type argument may be aided by the novel suggestion advanced by Brian Slattery to the effect that the various Acts that received the English common law into the provinces must surely be subject to the Charter, and since those common law rules are adopted wholesale, except to the extent that they are inapplicable to the particular provincial legal and social regime, the rules themselves must also face up to the Charter. ${ }^{101}$ It would be untenable, according to Slattery, if the Crown were to escape the strictures of the Charter merely by accepting the common law and not reducing it to legislative form.

Attractive though it is, this viewpoint is not entirely satisfactory. It surely cannot make the whole of the common law subject to the Charter; at most it makes sense only so far as the law stood at the date of reception. Could a rule be discovered that had been received and not modified since reception, but had otherwise not been brought into an overall scheme of statute and common law, a litigant might succeed on the reception argument alone. However, since the common law has undergone a fairly steady revision, a rule of the common law, modified since reception but not brought into a Coates-type scheme, would likely not exhibit the requisite government approval of its modified form.

The Coates reasoning remains the strongest for bringing parts of the common law into the constitutional fold. In fact, it may have been anticipated in the only slightly earlier case of $R$. v. Kopyto, ${ }^{102}$ a decision of the Ontario Court of Appeal. The accused was a lawyer who had made certain comments following an unsuccessful action against the R.C.M.P. on behalf of a friend. The lawyer was convicted of contempt for scandalizing the court, a common law criminal offence preserved

100. J.A. Manwaring, "Bringing the Common Law to the Bar of Justice: A Comment on the Decision in the Case of Dolphin Delivery Lid." (1987) 19 On. L. Rev. 413 at 443.

For a similar view, see Howse, supra $\mathbf{n} .58$ at 251 : "It is plausible that, where common law doctrine has been left intact, this itself constitutes a conscious public choice - particularly in such a highly regulated area as labour relations".

101. Slattery, supra $\mathbf{n} .41$ at $\mathbf{9 1 0 - 9 1 6 .}$

102. Supra n.78. 
by the broad language of $s .8$ of the Criminal Code ${ }^{103}$ The majority of the Court of Appeal considered that Mr. Kopyto's comments were such that he could be convicted of the offence as it was then defined. However, the majority was prepared to test the offence of scandalizing the court against the rights and freedoms entrenched in the Charter. Cory J.A. said:

[T] ]he advent of the Charter of Rights makes it necessary to review the offence of scandalizing the court in order to ensure that it meets the requisite constitutional standards. ${ }^{104}$

Although the case was heard and decided after Dolphin Delivery, the Court only referred to those parts of McIntyre J.'s reasons dealing with freedom of expression, reasons that are clearly obiter dicta given the central decision that the common law rule in question was immune from Charter analysis. The Ontario Court of Appeal ignored the Supreme Court of Canada's unequivocal ruling that the common law simpliciter is not caught in the constitutional web, and went on to conclude that the common law rule regarding scandalizing the court infringed s.2(b) and was not a reasonable limit under s.1. Cory J.A. was, however, careful to explain that his decision did not mean that the offence no longer existed; it continued to exist, but with a different and heavier onus on the Crown to demonstrate, in the words of American jurisprudence, "a clear and present danger to the administration of justice". ${ }^{105}$ The result sought in Coates was similar, in that The Citizen wished only to remove the reverse onus provisions of Nova Scotia defamation law and to set up a defence of qualified privilege.

Dissenting in part in Kopyto, Dubin J.A. merely said:

Contempt of court is a criminal offence. Although for its definition, one must resort to the common law, the offence is subject to a Charter challenge as are criminal offences which are defined in the Criminal Code. ${ }^{106}$

This assertion is a curious one in light of Dolphin Delivery, since nowhere does the Supreme Court of Canada draw a distinction between criminal and non-criminal rules of law, only between common and statutory law. Without more, the common law criminal offence should escape Charter review. The irresistably attractive inference to be made is that Dubin J.A., and the majority for that matter, are assuming that because s. 8 of the Criminal Code contemplates the existence of common law crimes, there is a sufficient governmental nexus. If such is not the basis of their decision, then the author would respectfully suggest that the decision in the case is incorrect.

It is worth noting as well, that Hoogbruin v. A. -G. B.C. ${ }^{107}$ is also potentially explainable in terms of the Coates reasoning. The statutory provision in question first enunciated the right to vote, but provided insufficient mechanism to give full effect to the right. The explicit recognition of the right to vote may have embodied a sufficient governmental connection with the failure to provide an absentee voting procedure that the omission became a government "act" and therefore subject to Charter review. If cogent, such reasoning is not apparent on the face of the decision.

103. R.S.C. 1970 , c.34.

104. Supra n.78 at 89.

105. Id. at 102.

106. Id. at 127.

107. Supra n.64.

108. Supra n.91. 


\section{McIntyre J.'s "Lifeline"}

Although McIntyre J. sought to exclude the bulk of the common law from strict Charter review, he was careful to instruct the courts that they ought to "develop and apply" the common law in light of Charter principles. In keeping with the remainder of his judgment, His Lordship offered no explanation of this instruction, specifically whether the review process is the same as with strict Charter cases and merely a different remedy, or whether the review process itself is somehow different.

It was not necessary to decide the issue in Coates because of the view (apparently) taken of the Charter's application to the common law, however counsel for The Citizen had advanced this type of argument in its memorandum. In the event that the court could not find the requisite governmental nexus as urged by the Citizen, it was argued that the defamation law of Nova Scotia be developed and applied in conformity with the Charter. What this argument amounted to was a request for something akin to a "constitutional exemption" - except that the constitution (i.e. Charter) was not directly applicable - the idea being that the courts must "on a case by case basis, apply and develop the common law consistently with the Charter', ${ }^{109}$ Had the court resorted to this reasoning, the result, presumably, would have been to require, in this case, that the reverse onus provisions under attack not be applied to the Citizen. As was noted previously, this approach seems to represent little more than a full Oakes test, without the declaration of "no force and effect", but rather a simple ruling that the rules do not apply in the particular case. ${ }^{110}$

Since Richard J. did not consider this argument, there are as yet no direct judicial pronouncements as to its nature or efficacy. Both $M c B e t h^{111}$ and Kopyto ${ }^{12}$ are consistent with this less defined approach to Charter review of the common law. However, both cases disclose a full-blown Oakes-type review of the common law rule and an ostensible declaration of no force and effect thereof. It is extremely unlikely that McIntyre J. meant "develop and apply" to mean "full-blown Oakes review" since his general ruling with respect to the common law would effectively be nullified. It is more likely that the Supreme Court of Canada, feeling that it was too early in the history of constitutional rights and freedoms to make a sweeping pronouncement on the application of the Charter, ${ }^{113}$ instead settled on a compromise. The compromise is, however, fraught with unanswered questions, particularly as to whether a s. 1 analysis must be undertaken, and the type of remedy to be granted. The constitutional hoops may, in fact, be lowered for private litigants relying on or contesting the common law, allowing the courts to develop the law consistently with the Charter, without the more complex trappings of, and (superficially) more intrusive, review that has developed since Oakes. ${ }^{114}$

109. Supra n.93 at $48-49$.

110. The result seems at least superficially similar to that obtaining in judicial review of state legislation by the United States Supreme Court, where the ruling is that a provision (of statute law) cannot constitutionally be applied in a given case.

111. Supra n.79.

112. Supra n.78.

113. Keeping in mind, also, the paucity of evidence before it.

114. A.H. Lefever, pers. comm., October 31, 1988. 


\section{CONCLUSION}

Short of the Supreme Court's willingness to overrule itself, we are likely to find courts and advocates becoming nimbler in their manoeuvring through the shifting landscape of Dolphin Delivery. It is clear at least, that purely private action is immune from Charter review; it is less clear to what extent private litigation provides a vehicle for the constitutionalization of Canadian law. That statutory provisions are to be strictly assessed under the Charter is the only incontestable assertion that can be made.

The Charter in the context of private litigation is thus a fertile field for argument. That much is clear from the foregoing. Not only can we expect to see the law developing in intriguing ways around Dolphin Delivery, it would not be stretching the realm of possibility to suggest that the Supreme Court of Canada will one day reconsider its position. At that time, we can only hope that it adopts a reasonable approach to the issue, and not the puzzlingly inconsistent one it chose in Dolphin. 